\title{
Kualitas spermatozoa post-thawing pejantan sapi Friesian Holstein pada umur yang berbeda
}

\section{The quality of post-thawing spermatozoa of Holstein Friesian bull at different ages}

\author{
Widya Aulia Ristiani ${ }^{1}$, Muhammad Yunus ${ }^{2}$, Tri Wahyu Suprayogi ${ }^{3}$, Pudji Srianto ${ }^{3}$, \\ Imam Mustofa ${ }^{3}$, Rimayanti $^{3^{*}}$ \\ ${ }^{1}$ Mahasiswa, ${ }^{2}$ Departemen Parasitologi Veteriner, ${ }^{3}$ Departemen Reproduksi Veteriner \\ Fakultas Kedokteran Hewan, Universitas Airlangga \\ *Penulis koresponden, e-mail: rimayanti@fkh.unair.ac.id
}

\begin{abstract}
This study aimed to determine the post-thawing spermatozoa quality of Holstein-Friesian (HF) bulls at different ages. The samples were HF frozen semen of 3, 5, and 8-years -old age group produced by the Singosari National Artificial Insemination Center. Nine samples of each group were randomly purposive sampling, thawed in $37^{\circ} \mathrm{C}$ water for 15 seconds, and assessed on the percentage of viability, motility, and abnormality of spermatozoa. The obtained data were analyzed using the ANOVA method, followed by Duncan's multiple range test at a 95\% confidence level. The result showed that post-thawing spermatozoa viability in 5 and 8 -year-old HF bull were $67 \pm$ $6.67 \%$, and $78 \pm 7.59$, both were higher ( $p<0.05$ ) compared to $62.78 \pm 5.76 \%$ in HF bulls 3 -yearsold group. Likewise, the motility of those bull aged 5 and 8 years $(69.44 \pm 6.82$ and $65.00 \pm 9.68 \%$, respectively) were higher ( $\mathrm{p}<0.05$ ) compared to $55,56 \pm 5.83 \%$ in 3 -year-old HF bull. Meanwhile, the percentage of post-thawing spermatozoa abnormalities in the three age groups were $4.33 \pm$ $1.96 \%, 5.89 \pm 1.90 \%$, and $5.33 \pm 1.41 \%$, not significantly different ( $p>0.05$ ) respectively. It concluded that the best quality of post-thawing HF semen based on the percentage of viability, motility, and morphologic abnormality was collected from 5-8 years old bull. Nevertheless, spermatozoa from the three age goups still meet the Indonesia standard quality of frozen semen for artificial insemination.
\end{abstract}

Keywords: Holstein-Friesian bull, sperm quality, post thawing, different ages

\section{PENDAHULUAN}

Produkivitas susu dan perolehan anak sapi merupakan sumber keuntungan pada usaha beternak sapi perah. Produktivitas susu dipengaruhi oleh keunggulan nilai genetik yang bersama dengan pengaruh lingkungan (pakan, manajemen dan pengendalian penyakit) selanjutnya akan menghasilkan fenotip sapi perah yang menguntungkan secara ekonomi. Salah satu cara untuk meningkatkan produktivitas adalah dengan meningkatkan efisiensi reproduksi, karena produksi susu merupakan bagian dari sistem reproduksi sapi induk. Peningkatan kemampuan produksi dan reproduksi ternak dapat dilakukan dengan diaplikasikannya Inseminasi Buatan (IB). Teknologi IB merupakan teknik utama dalam produksi ternak dan sangat penting untuk seleksi genetik (Waberski, 2018), dan telah terbukti berhasil di seluruh dunia untuk memajukan peternakan dengan percepatan dan seleksi genetik (Medeiros et al., 2002). Teknik IB telah digunakan lebih dari $90 \%$ perkawinan sapi perah di Indonesia, menggunakan semen beku pejantan Friesian Holstein $(\mathrm{FH})$ produksi dari Balai Besar Inseminasi Buatan maupun Balai Inseminasi Buatan Daerah. 
Sifat produktivitas sapi perah setengahnya berasal dari gen induk dan setengah yang lain dari gen pejantan. Dengan demikian, pemilihan pejantan sapi FH unggul sangat penting untuk untuk meningkatkan produktivitas sapi perah. Oleh karena itu, dalam upaya penyediaan semen beku sapi perah yang berkualitas untuk IB diperlukan pejantan FH yang memiliki produktivitas semen, kualitas spermatozoa yang baik, dan terbukti secara progeny menghasilkan keturunan yang unggul pula (Medeiros et al., 2002).

Kualitas spermatozoa mempunyai peranan penting dalam IB, sehingga perlu dilakukan pemeriksaan dengan teliti dan hati-hati. Kualitas spermatozoa dapat dipengaruhi oleh beberapa faktor, yaitu umur, pakan, genetik, suhu dan musim, kesehatan, frekuensi ejakulasi, besar testis, dan bangsa ternak (Susilowati et al, 2010 ; Ismaya, 2014). Umur pejantan merupakan salah satu faktor yang mempengaruhi kualitas spermatozoa. Peningkatan umur berpengaruh terhadap peningkatan kadar testosteron, sehingga meningkat pula produksi dan kualitas spermatozoa, meskipun pada batas umur tertentu akan diikuti dengan penurunan kualitas spermatozoa (Ismaya, 2014). Berdasarkan latar belakang tersebut dilakukan penelitian mengenai kualitas (persentase viabilitas, motilitas, dan abnormalitas morfologi) spermatozoa post-thawing pejantan sapi $\mathrm{FH}$ pada umur yang berbeda.

\section{MATERI DAN METODE}

Sampel yang digunakan dalam penelitian ini adalah semen beku sapi Friesian Holstein (FH) berasal dari Balai Besar Inseminasi Buatan (BBIB) Singosari - Malang. Semen beku berasal dari sapi perah FH umur 3 tahun, 5 tahun dan 8 tahun, dengan pengambilan sampel secara acak menggunakan teknik random purposive sampling.

\section{Pemeriksaan viabilitas spermatozoa}

Satu tetes semen diteteskan di atas gelas obyek dan ditambahkan dengan satu tetes oesinnegrosin, kemudian dibuat preparat ulas dan difiksasi di atas api bunsen. Preparat diamati menggunakan mikroskop dengan perbesaran 400 kali dan dihitung 100 spermatozoa. Spermatozoa hidup tampak tidak menyerap warna (putih transparan), sedangkan spermatozoa mati berwarna merah keunguan (Sardjito, 2014). Viabilitas dihitung dalam bentuk persentase spermatozoa yang tidak menyerap warna.

\section{Pemeriksaan motilitas spermatozoa}

Sampel semen diteteskan di atas gelas obyek dan ditambahkan $\mathrm{NaCl}$ fisiologis dengan perbandingan $1: 1$, kemudian diamati menggunakan mikroskop dengan perbesaran 400 kali. Penilaian dilakukan dengan menghitung persentase spermatozoa yang pergerakannya progresif maju ke depan dari 100 spermatozoa (Susilowati et al, 2010).

\section{Pemeriksaan abnormalitas spermatozoa}

Pengamatan terhadap abnormalitas spermatozoa dilakukan menggunakan mikroskop cahaya (Olympus $\mathrm{CH}$ 20) dengan perbesaran 400 kali. Penghitungan jumlah abnormalitas dilakukan minimal 500 sel spermatozoa dari 5-10 lapang pandang yang berbeda. Abnormalitas spermatozoa yang diamati dikelompokkan menjadi pyriform (bentuk yang menyempit di bagian post acrosome), detached head (kepala yang terpisah dari ekor), pear shaped (bagian anterior akrosom membulat dan bagian posterior akrosom mengecil dan mengalami elongasi seperti buah pir), macrocephalus (kepala lebih besar), microcephalus (kepala lebih kecil), double head (satu sel memiliki dua kepala dan satu ekor), nuclear vacuolus (terdapat vakuola di bagian kepala spermatozoa yang menunjukan abnormalitas inti dan kromatin sel), round head (bentuk kepala yang membulat), abnormal countour (bentuk yang abnormal di kepala maupun ekor), abaxial (terbentuk fossa perlekatan di bagian tengah ekor), abnormal decondensation (abnormalitas kondensasi DNA spermatozoa), decapasitation (mengalami kapasitasi dini), defect midpiece (kerusakan pada bagian mid piece seperti ekor yang melingkar, patah dan melipat), dan distal cytoplasmic droplet (Barth dan Oko, 1989). 


\section{Analisis statistik}

Data yang diperoleh dianalisis dengan uji homogenitas Kolmogorov dan Smirnov. Data yang homogen dilanjutkan dengan uji parametrik dengan metode ANOVA pada tingkat kepercayaan 95\%. Apabila terdapat perbedaan signifikan antar kelompok perlakuan dilanjutkan dengan uji jarak berganda Duncan (Kusriningrum, 2009).

\section{HASIL}

Viabilitas post-thawing spermatozoa pada sapi FH yang berumur 5 dan 8 tahun, keduanya lebih tinggi $(\mathrm{p}<0,05)$ dibandingkan pada sapi FH yang berumur 3 tahun. Sedangkan viabilitas spermatozoa sapi pejantan $\mathrm{FH}$ umur 5 dan 8 tahun tidak berbeda nyata $(\mathrm{p}>0,05)$. Motilitas post-thawing spermatozoa pada sapi $\mathrm{FH}$ yang berumur 5 dan 8 tahun, juga lebih tinggi ( $p$ $<0,05)$ dibandingkan pada sapi $\mathrm{FH}$ yang berumur 3 tahun. Sedangkan motilitas spermatozoa dari sapi pejantan $\mathrm{FH}$ yang berumur 5 dan 8 tahun tidak berbeda nyata ( $\mathrm{p}$ $>0,05)$. Persentase abnormalitas spermatozoa pada kelompok sapi FH umur 3 tahun, 5 tahun, dan 8 tahun tidak berbeda nyata $(\mathrm{p}>0,05)$ (Tabel 1).

Tabel 1 Viabilitas, motilitas, dan abnormalitas spermatozoa (\%, rata-rata \pm SD) post thawing pada pejantan sapi FH perah umur 3, 5 dan 8 tahun.

\begin{tabular}{cccc}
\hline umur sapi & viabilitas & motilitas & abnormalitas \\
\hline 3 tahun & $62,8 \pm 5,8^{\mathrm{a}}$ & $55,6 \pm 5,8^{\mathrm{a}}$ & $4,3 \pm 2,0^{\mathrm{a}}$ \\
5 tahun & $78,7 \pm 6,7^{\mathrm{b}}$ & $69,4 \pm 6,8^{\mathrm{b}}$ & $5,9 \pm 1,9^{\mathrm{a}}$ \\
8 tahun & $77,8 \pm 7,6^{\mathrm{b}}$ & $65,0 \pm 9,7^{\mathrm{b}}$ & $5,3 \pm 1,4^{\mathrm{a}}$ \\
\hline
\end{tabular}

${ }^{\mathrm{a}, \mathrm{b}}$ Superskrip yang berbeda pada kolom yang sama menunjukkan adanya perbedaan yang nyata (p $<0,05)$.

\section{DISKUSI}

\section{Viabilitas dan motilitas spermatozoa}

Viabilitas post-thawing spermatozoa pada sapi FH umur 5 dan 8 tahun keduanya lebih tinggi dibandingkan pada sapi FH pejantan unur 3 tahun. Persentase hidup spermatozoa ditentukan oleh membran plasma yang utuh, karena membran plasma spermatozoa berfungsi melindungi organel spermatozoa dan transport elektrolit untuk metabolisme spermatozoa (Salmah, 2014). Membran plasma dapat berpengaruh pada fungsi fisiologis dan metabolisme spermatozoa. Rusaknya membran plasma menyebabkan terganggunya proses metabolisme dan proses fisiologis spermatozoa sehingga menyebabkan kematian spermatozoa. Keutuhan membran plasma juga sangat berkolerasi dengan daya gerak spermatozoa. Apabila membran plasma spermatozoa sudah mengalami kerusakan, maka metabolisme spermatozoa akan terganggu sehingga spermatozoa akan kehilangan daya gerak dan mengakibatkan kematian sel (Butarbutar, 2009). Metabolisme spermatozoa dapat mempengaruhi daya hidup spermatozoa. Aktivitas metabolisme tinggi pada spermatozoa dapat menghasilkan asam laktat yang tinggi pula sehingga dapat membunuh spermatozoa (Varasofiari et al., 2013).

Motilitas post-thawing spermatozoa pada sapi FH umur 5 dan 8 tahun lebih tinggi dibandingkan pada sapi pejantan $\mathrm{FH}$ umur 3 tahun. Namun motilitas post-thawing spermatozoa pada sapi FH tiga kelompok umur tersebut semuanya masih memenuhi persyaratan Standar Nasional Indonesia (SNI) 4869-1:2017 yaitu minimal $40 \%$ (Badan Standardisasi Nasional, 2017). Nilai motilitas pada sapi pejantan $\mathrm{FH}$ yang lebih tua (umur 5 dan 8 tahun) lebih baik daripada sapi pejantan $\mathrm{FH}$ umur 3 tahun terjadi karena faktor genetik masing-masing pejantan dan perbedaan ketersediaan sumber energi berupa fruktosa, sorbitol, dan glycerylphosporilcholine (GPC) yang dapat mempengaruhi motilitas 
spermatozoa (Susilawati et al., 1993). Membran plasma yang utuh juga memiliki korelasi dengan motilitas spermatozoa, semakin banyak membran plasma spermatozoa yang utuh maka semakin banyak spermatozoa yang motil (Azzahra et al., 2016). Hasil penelitian ini sesuai dengan beberapa penelitian terdahulu yang dilakukan pada jenis sapi lain. Penelitian pada sapi Simmental menunjukkan persamaan regresi antara umur dengan presentase motilitas individu sapi memperlihatkan adanya penurunan secara perlahan setelah umur 100 minggu ( 2 tahun) dan mengalami peningkatan kembali pada umur di atas 300 minggu (5-7 tahun) (Lestari et al., 2013). Demikian juga pada sapi Simmental mempunyai total spermatozoa yang mengalami penurunan setelah umur 3 tahun dan mengalami peningkatan pada umur 7 tahun (Nyuwita et al.,2015).

Pada sapi pejantan Jersey volume ejakulat, konsentrasi spermatozoa, viabilitas, normalitas morfologi, motilitas spermatozoa pada semen segar, pre-filling, dan motilitas post-thawing, lebih tinggi pada sapi pejantan berumur 5-7 tahun dibandingkan usia yang lebih muda maupun yang lebih tua (Sankhi et al., 2018). Pada sapi pejantan Simmental tua (umur 12 tahun atau lebih) ejakulat mencapai volume tertinggi, tetapi konsentrasi spermatozoa, jumlah spermatozoa total, motilitas postthawing rendah sehingga dosis semen beku juga rendah (Isnaini et al., 2019).

\section{Abnormalitas Spermatozoa}

Hasil pengamatan pada rataan abnormalitas spermatozoa pada kelompok sapi $\mathrm{FH}$ umur 3 tahun, 5 tahun, dan 8 tahun berkisar antara 4 $6 \%$ (Tabel 1). Hasil penelitian ini menunjukkan bahwa perbedaan umur tidak berpengaruh pada abnormalitas spermatozoa. Spermatozoa post thawing yang berasal dari ke tiga umur yang berbeda tersebut masih memenuhi kriteria semen berkualitas baik. Hal ini sesuai dengan laporan sebelumnya bahwa umur pejantan tidak mempengaruhi persentase dan jenis abnormalitas spermatozoa (Menon et al., 2011). Penelitian pada sapi Aceh juga membuktikan bahwa umur tidak berpengaruh terhadap persentase spermatozoa abnormal (Melita et al, 2014). Persentase abnormalitas morfologi spermatozoa sapi pejantan $\mathrm{FH}$ pada sampel semen yang dikumpulkan dari tiga pusat AI di Indonesia berada dalam kisaran normal, yaitu antara $1-8,40 \%$ (Purwantara et al., 2010).

Abnormalitas morfologi spermatozoa pada penelitian ini tidak berbeda nyata berdasarkan perbedaan umur. Hal ini disebabkan rentangan umur pejantan tersebut masih dalam batas masa produktif. Pejantan FH yang berusia kurang dari satu tahun produksi volume ejakulat dengan semua parameter (konsentrasi, viabilitas dan motilitas) lebih rendah dibandingkan dengan sapi jantan yang lebih dari satu tahun (Murphy et al., 2018). Presentase abnormalitas dari semua kelompok umur yang masih dalam kisaran baik. Abnormalitas kurang dari 20\% masih dalam batas normal (Garner dan Hafez, 2008). Abnormalitas morfologi spermatozoa post-thawing yang tinggi berasosiasi dengan infertilitas dan sterilitas (Purwantara et al., 2010).

\section{KESIMPULAN}

Kualitas post-thawing spermatozoa sapi pejantan FH yang terbaik berdasarkan persentase viabilitas, motilitas, dan abnormalitas morfologis berasal dari semen sapi pejantan berumur 5-8 tahun. Meskipun demikian, spermatozoa dari ketiga umur tersebut masih memenuhi standar SNI kualitas semen beku untuk inseminasi buatan.

\section{DAFTAR PUSTAKA}

Azzahra FT, Setiatin ET, Samsudewa D. 2016. Evaluasi motilitas dan presentase hidup semen segar Sapi PO Kebumen pejantan muda. Fakultas Peternakan dan Pertanian Universitas Diponegoro Semarang. J Sains Peternakan Indonesia 2: 99-107.

Badan Standarisasi Nasional Indonesia (BNSI) 2017. SNI (Standar Nasional Indonesia) 4869-1. Semen beku - Bagian 1: Sapi. Jakarta, Indonesia. 
Barth AD, Oko RJ. 1989. Abnormal morphology of bovine spermatozoa. Iowa State University Press. Iowa.

Butarbutar E. 2009. Efektifitas frekuensi exercise terhadap peningkatan kualitas semen sapi Simmental. Skripsi. Fakultas Pertanian universitas Sumatra Utara. 23-50.

Garner DL, Hafez ESE. 2008. Spermatozoa and Seminal Plasma. Dalam: Hafez ESE (editor). Reproduction in Farm Animmal. Edisi 7. Lea and Febiger: 96-110.

Ismaya. 2014. Bioteknologi inseminasi buatan pada sapi dan kerbau. Yogyakarta: Gadjah Mada University Press. 12.

Isnaini $\mathrm{N}$, Wahjuningsih $\mathrm{S}$, Ma'ruf $\mathrm{A}$, Witayanto DA. 2019. Effects of age and breed on semen quality of beef bull sires in an Indonesian artificial insemination center. Livestock Research for Rural Development.

http://www.lrrd.org/lrrd31/5/nurul31078.ht ml.

Kusriningrum. 2009. Buku ajar perancangan percobaan. Dani Abadi. Surabaya. 31.

Lestari S, Saleh DM, Maidaswar M. 2013. Profil kualitas semen segar sapi pejantan Limousin dengan umur yang berbeda di Balai Inseminasi Buatan Lembang Jawa Barat. J Ilmu Peternakan. 1: 1165-72.

Medeiros CMO, Forell F, Oliveira ATD, Rodrigues JL. 2002. Current status of sperm cryopreservation: why isn't it better? Theriogenology 57: 327-44

Melita D, Dasrul D, Adam M. 2014. Pengaruh umur pejantan dan frekuensi ejakulasi terhadap kualitas spermatozoa sapi Aceh. J Medika Veterinaria 8: 15-9.

Menon AG, Barkema HW, Wilde R, Kastelic JP, Thundathil JC. 2011. Associations between sperm abnormalities, breed, age, and scrotal circumference in beef bulls. Can J Vet Res. 75: 241-247.

Murphy EM, Kelly AK, O'Meara C, Eivers B, Lonergan P, Fair S. 2018. Influence of bull age, ejaculate number, and season of collection on semen production and sperm motility parameters in Holstein Friesian bulls in a commercial artificial insemination centre. J Anim Sci. 96:
2408-18.

Nyuwita AT, Susilawati T, Isnaini N. 2015. Kualitas semen segar dan produksi semen beku sapi Simmental pada umur yang berbeda. Ternak Tropika 16: 1-8

Purwantara B, Arifiantini RI, Riyadhi M. 2010. Sperm morphological assessments of $\mathrm{FH}$ bull semen collected from three Artificial Insemination Centers in Indonesia. $\mathbf{J}$ Indonesian Trop. Anim. Agric. 35: 90-4.

Salmah N. 2014. Motilitas, presentase hidup dan abnormalitas spermatozoa semen beku sapi Bali pada pengenceran andromed dan tris kuning telur. Skripsi. Fakultas Peternakan Universitas Hasanuddin. Makassar. 37-8.

Sankhi S, Sapkota KR, Regmi B. 2018. Effect of age and frequency of collection in quality of Jersey bulls semen at National Livestock Breeding Center, Nepal. Nepalese Vet J. 35: 9-22.

Sardjito T. 2014. Identifikasi kasus infertilitas dan pola pita protein gel SDS PAGE serum sapi betina Crossbreed Baluran dan perubahan molekuler DNA pada semen pejantan baluran post thawing. Laporan Penelitian Universitas Airlangga.

Susilawati T, Suyadi N, Isnaini N, Wahyuningsih S. 1993. Kualitas semen sapi Fries Holland dan sapi Bali pada berbagai umur dan berat badan. Laporan Penelitian. Fakultas Peternakan Universitas Brawijaya, Malang.

Susilowati S, Hardijanto H, Suprayogi TW, Sardjito T, Hernawati T. 2010. Petunjuk praktikum inseminasi buatan. Airlangga University Press. Surabaya. 5-37.

Varasofiari LN, Setiatin ET, Sutopo S. 2013. Evaluasi kualitas semen segar sapi Jawa Brebes berdasarkan lama waktu penyimpanan. Fakultas Peternakan dan Pertanian Universitas Diponegoro Semarang. Animal Agriculture 1: 201-108.

Waberski D. 2018. Artificial insemination in domestic and wild animal species. Dalam: Niemann H, Wrenzycki C (editor). Animal biotechnology 1. Springer International Publishing AG part of Springer Nature. 3764. 
Widya A Ristiani et al., 2020/Ovozoa 9: 12-16 